\title{
Minimum Dietary Diversity Score and Associated Factors among Pregnant Women at Alamata General Hospital, Raya Azebo Zone, Tigray Region, Ethiopia
}

\author{
Kemal Jemal (iD) and Mukemil Awol \\ College of Health Sciences, School of Nursing and Midwifery, Salale University, Fitche, Ethiopia \\ Correspondence should be addressed to Kemal Jemal; olifanjemal@gmail.com
}

Received 21 September 2018; Revised 26 February 2019; Accepted 26 March 2019; Published 2 May 2019

Academic Editor: H. K. Biesalski

Copyright (c) 2019 Kemal Jemal and Mukemil Awol. This is an open access article distributed under the Creative Commons Attribution License, which permits unrestricted use, distribution, and reproduction in any medium, provided the original work is properly cited.

\begin{abstract}
Background. Consumption of diversified food during pregnancy found very important and critical to determine healthy pregnancy outcome. Low dietary diversity has a major adverse effect on mothers, fetus, and life of new born. Dietary diversity is still low in low-resourced countries. Therefore, this study aims to determine prevalence of minimum dietary diversity score (MDDS) and associated factors among pregnant women. Methods. Facility-based cross-sectional study was conducted from April to May, 2017, in Alamata General Hospital (AGH). Data were collected using a pretested and structured self-interview questionnaire. A systematic sampling technique was used to select study participants. Binary logistic regression and odds ratio with $95 \%$ confidence interval (CI) were carried out to see the association between variables and the outcomes. Results. From a survey of 412 participants, $61.2 \%$ had high MDDS and 38.8\% had low MDDS. Multivariate analysis revealed that being government employees ( $\mathrm{AOR}=4.87, \mathrm{CI}: 1.70-13.95)$, merchant ( $\mathrm{AOR}=4.67, \mathrm{CI}: 1.81-12.05)$, secured food (AOR $=3.85$, $\mathrm{CI}$ : 2.12-6.97), and eating three meals and above $(\mathrm{AOR}=2.66, \mathrm{CI}: 1.47-4.82)$ were significantly associated with high MDDS among pregnant women. Conclusions. In our study, minimum dietary diversity shows small increment from previous study. Screening and special emphases should be given by a health-care provider on women diet during antenatal follow-up at health-care settings.
\end{abstract}

\section{Background}

An inadequate dietary diversity is the main concern for pregnant women all over the world. Dietary diversity defined as the number of different food groups consumed over a given reference period [1]. It is the consumption of different food groups within 24 hours prior to assessment [2]. Daily calorie consumption among pregnant women is supposed to be from 2,200 to 2,900 calories [3]. The need for iron is greatly important as it involves the formation of red blood cells and fetal stores [4]. Nonpregnant and pregnant women are requiring iron up to $18 \mathrm{mg} / \mathrm{d}$ and $27 \mathrm{mg} / \mathrm{d}$, respectively [5]. During pregnancy, women were required $770 \mu \mathrm{g} / \mathrm{d}$ of vitamin $\mathrm{A}$ and $600 \mu \mathrm{g} / \mathrm{d}$ iron foliate which obtained from enriched cereal, dark leafy vegetables, and bread products [6].

In the United States of America, 9.5\% of women were inadequate in iron and $<1 \%$ of the American population were deficient in both vitamin E and foliate [7]. In Pakistan, $86 \%$ of pregnant women have medium, $5 \%$ have low, and $9 \%$ have a high dietary diversity score [8].

In sub-Saharan African countries, diets are predominantly based on starchy foods with little or no animal products and few fresh fruits and vegetables [9]. In Tanzania, cereals and starchy roots contribute $51 \%$ and $19 \%$ of the total dietary energy supply and $71 \%$ and $61 \%$ of population use production of maize and rice, respectively $[10,11]$. Study in Ghana found that $46.1 \%$ pregnant women get their dietary need while $43.9 \%$ were not [12]. In Kenya, the prevalence of MDDS was found that $74.5 \%$ participants had medium dietary score, $20 \%$ of respondents had high dietary score, and $6 \%$ had low dietary diversity score [13]. A survey done in Axum, Ethiopia, found that $56.4 \%$ and $43.6 \%$ had the low and high dietary diversity scores, respectively [14]. 
A pregnant mother who may not take an adequate nutrient at first trimesters of pregnancy may have high rate of fetal morbidity and mortality [15]. Such insufficient dietary intake may lead to low birth weight, still birth, premature rapture of membrane, intrauterine growth restriction, intrauterine fetal death, and congenital anomalies and affect later on sudden infant death syndrome, developmental impairment, malnutrition, and risk for chronic disease [16-18].

Women who live in developing countries were at high risk for micronutrient akin to vitamins $\mathrm{A}$ and $\mathrm{D}$, iron, iodine, folic acid, and vitamins B1, B6, and B12, which may affect the outcome of pregnancy [19-21]. Inadequate consumption of vitamin A during pregnancy can lead to premature birth, eye abnormalities, and impaired vision [22-24].

There were a few studies done in Ethiopia, and little is known on the effect of dietary diversity among reproductive women. To date, there are no studies on the maternal dietary diversity score among pregnant women in the study area. Therefore, the objectives of this study are to [1] determine the prevalence of the maternal dietary diversity score in pregnant women and [2] identify factors associated with pregnant women at $\mathrm{AGH}$.

\section{Methods}

2.1. Study Design and Period. An institutional crosssectional study was conducted from April to May, 2017, in an urban district maternal child health $(\mathrm{MCH})$ clinic.

2.2. Study Setting. Alamata is one of the district towns in Rayya Azebo Zone, Tigray region, Ethiopia. It is located in north 600 kilometer from the capital city of Ethiopia (Addis Ababa) and 180 kilometer from the capital city of Tigray region (Mekelle). In Alamata town, there is one general hospital, one health center, and four private clinics. The AGH services a population of greater than 59,915 people with different four major departments including medical, surgical, pediatrics, and obstetrics and gynecology. It also provides outpatient service, emergency, ophthalmology, ART clinic, and MCH clinic.

2.3. Study Population. The study population consisted of all pregnant women who were on follow-up at $\mathrm{AGH}$ from 16 weeks gestational age, which were included in the sample.

2.4. Exclusion Criteria. Pregnant women who were unable to speak/hear and had been seriously ill during data collection were excluded from the study.

2.5. Sampling Procedure. The sample size was determined based on a single population proportion formula using Epi Info version 7 with a $95 \%$ CI and 5\% margin of error and taking 53\% proportion of reproductive age women with MDDS that was done in Gojam, Ethiopia [25]. A 10\% nonresponse rate was assumed, and 420 sample sizes were estimated. The study participants were selected using a systematic sampling technique. The sampling interval was determined by calculating monthly average attendance for antenatal care follow-up divided by the required sample size, and then, the first study participant was selected randomly.

2.6. Data Collection. Pretested and structured selfadministered interview questionnaires were used to collect data by trained midwifery professionals. The questionnaire contained three parts. The first part includes sociodemographic characteristics (age, marital status, residence, education, occupation, and others). The second parts were dietary information questionnaires. It contained ten different food groups based on their nutrients: those include grains (white roots, tubers, and plantains), pulses (beans, peas, and lentils), nuts and seeds, dairy, meat (poultry and fish), eggs, dark green leafy vegetables, vitamin A-rich fruits and vegetables, vegetables, and fruits. The third components were food security questionnaires which were categorized into three based on the number of questionnaires they answered (secured food, unsecured food without hunger, and unsecured food with hunger). Women who eat five or more and less than five different food groups have a high and low dietary diversity score, respectively [26, 27].

2.7. Data Processing and Analyses. Completed questionnaires were checked for accuracy and completeness in recoding of responses. The data were edited, coded, and cleaned prior to data entry. Data were entered into Epidata version 3.1 and analyzed by using SPSS version 20. Description of means, frequencies, proportions, and rates of the given data for each variable was calculated. Frequencies and percentages for discrete data (noncontinuous) were done. Logistic regression was completed to test for relationship between factors and the dietary diversity of the respondents. A $P$ value of $<0.05$ was used as the criteria for statistical significance.

2.8. Ethical Consideration. Ethical clearance was obtained from Woldia University, Faculty of Health Sciences, Department of Midwifery and Research Committee. The permission letter was granted from AGH. Written informed consent was obtained from each study participant. Data collectors were clarified the purpose of the study and assured the confidentiality of the study respondents. To keep privacy of the respondents, the name and any identity were not included in the data collection questionnaire.

\section{Results}

From 420 planned participants, 412 were included in the study with a response rate of $98 \%$. Majority of the participants $(34.5 \%)$ were unable to read and write while onefourth of the household were able to write and read, and $28.6 \%$ were college and above. Greater than three-fourths of study participants had family size below five and high monthly income (Table 1).

3.1. Dietary Intake, Food Security, and Comorbidity Status of the Respondents. A $98.5 \%$ of study population had consumed cereals in the period of 24 hours. The main cereal 
TABLE 1: Sociodemographic characteristics of study participants in $\mathrm{MCH}$ at AGH, Alamata town, $2017(n=412)$.

\begin{tabular}{|c|c|c|}
\hline Variable & Frequency & Percentage \\
\hline \multicolumn{3}{|l|}{ Age category } \\
\hline $18-29$ & 252 & 61.2 \\
\hline $30-39$ & 139 & 33.7 \\
\hline $40-49$ & 21 & 5.1 \\
\hline \multicolumn{3}{|l|}{ Marital status } \\
\hline Married & 402 & 97.6 \\
\hline Widowed & 3 & 0.7 \\
\hline Single & 7 & 1.7 \\
\hline \multicolumn{3}{|l|}{ Residence } \\
\hline Urban & 328 & 79.6 \\
\hline Rural & 84 & 20.4 \\
\hline \multicolumn{3}{|l|}{ Family member } \\
\hline Five and above & 86 & 20.9 \\
\hline Below five & 326 & 79.1 \\
\hline \multicolumn{3}{|l|}{ Ethnicity } \\
\hline Tigray & 388 & 94.2 \\
\hline Amhara & 19 & 4.6 \\
\hline Afar & 5 & 1.2 \\
\hline \multicolumn{3}{|l|}{ Age of household } \\
\hline $20-29$ & 79 & 19.2 \\
\hline $30-39$ & 234 & 56.8 \\
\hline 40 and above & 99 & 24.0 \\
\hline \multicolumn{3}{|l|}{ Source of drinking water } \\
\hline Tap water & 60 & 14.6 \\
\hline Pumping water & 335 & 81.3 \\
\hline Protected well & 17 & 4.1 \\
\hline \multicolumn{3}{|l|}{ Latrine } \\
\hline Yes & 354 & 85.9 \\
\hline No & 58 & 14.1 \\
\hline \multicolumn{3}{|l|}{ Home gardening practice } \\
\hline Yes & 140 & 34 \\
\hline No & 272 & 66 \\
\hline \multicolumn{3}{|l|}{ Main source of food } \\
\hline Market & 336 & 81.6 \\
\hline NGO/support & 10 & 2.4 \\
\hline Farmer/garden & 66 & 16 \\
\hline \multicolumn{3}{|l|}{ Maternal educational status } \\
\hline Unable to write and read & 143 & 34.7 \\
\hline Able to write and read & 46 & 11.2 \\
\hline Elementary school & 67 & 16.3 \\
\hline High and preparatory school & 92 & 22.3 \\
\hline College and above & 64 & 15.5 \\
\hline \multicolumn{3}{|l|}{ Household educational status } \\
\hline Unable to write and read & 118 & 28.6 \\
\hline Able to write and read & 62 & 15.1 \\
\hline Elementary school & 50 & 12.2 \\
\hline High and preparatory school & 64 & 15.5 \\
\hline College and above & 118 & 28.6 \\
\hline \multicolumn{3}{|l|}{ Occupation } \\
\hline House wife & 183 & 44.4 \\
\hline Merchant & 125 & 30.4 \\
\hline Government employee & 78 & 18.9 \\
\hline Daily laborer & 26 & 6.3 \\
\hline \multicolumn{3}{|l|}{ Monthly income } \\
\hline $0-500$ & 21 & 5.1 \\
\hline $501-1500$ & 66 & 16.0 \\
\hline 1501 and above & 325 & 78.9 \\
\hline
\end{tabular}

TABle 2: Consumption of food groups, food security, and comorbidity status of study participants in $\mathrm{MCH}$ at AGH, Alamata town, $2017(n=412)$.

\begin{tabular}{|c|c|c|}
\hline Variable & Frequency & Percentage \\
\hline \multicolumn{3}{|l|}{ Starchy staples } \\
\hline Yes & 406 & 98.5 \\
\hline No & 6 & 1.5 \\
\hline \multicolumn{3}{|l|}{ Vitamin A-rich fruit and vegetable } \\
\hline Yes & 168 & 40.8 \\
\hline No & 244 & 59.2 \\
\hline \multicolumn{3}{|l|}{ Other vegetables } \\
\hline Yes & 336 & 81.6 \\
\hline No & 76 & 18.4 \\
\hline \multicolumn{3}{|l|}{ Dark green leaf vegetable } \\
\hline Yes & 348 & 84.5 \\
\hline No & 64 & 15.5 \\
\hline \multicolumn{3}{|l|}{ Fruit } \\
\hline Yes & 92 & 22.3 \\
\hline No & 320 & 77.7 \\
\hline \multicolumn{3}{|l|}{ Meat, poultry, and fish } \\
\hline Yes & 131 & 31.8 \\
\hline No & 281 & 68.2 \\
\hline \multicolumn{3}{|l|}{ Egg } \\
\hline Yes & 141 & 34.2 \\
\hline No & 271 & 65.8 \\
\hline \multicolumn{3}{|l|}{ Pulses } \\
\hline Yes & 213 & 51.7 \\
\hline No & 199 & 48.3 \\
\hline \multicolumn{3}{|l|}{ Dairy } \\
\hline Yes & 203 & 49.3 \\
\hline No & 209 & 50.7 \\
\hline \multicolumn{3}{|l|}{ Nuts and seeds } \\
\hline Yes & 221 & 53.6 \\
\hline No & 191 & 46.4 \\
\hline \multicolumn{3}{|l|}{ Dietary diversity } \\
\hline High dietary diversity & 252 & 61.2 \\
\hline Low dietary diversity & 160 & 38.8 \\
\hline \multicolumn{3}{|l|}{ Food security status } \\
\hline Food secured & 281 & 68.2 \\
\hline Food unsecured without hunger food & 123 & 29.9 \\
\hline Unsecured with hunger & 8 & 1.9 \\
\hline \multicolumn{3}{|l|}{ Food eating pattern } \\
\hline Three meals and above & 102 & 24.8 \\
\hline Two meals and eating between meal & 295 & 71.6 \\
\hline Two meals only or below & 15 & 3.6 \\
\hline \multicolumn{3}{|l|}{ Illness in last 4 week before assessment } \\
\hline Yes & 54 & 13.1 \\
\hline No & 358 & 86.9 \\
\hline \multicolumn{3}{|l|}{ Types of illness } \\
\hline Malaria & 191 & 46.4 \\
\hline HIV/AIDS & 198 & 48.0 \\
\hline Others & 23 & 5.6 \\
\hline
\end{tabular}

Others: tuberculosis and diabetes mellitus.

consumed was teff, wheat, and maize that were considered as the staple food within the area. Also, vegetables were an integral part of nutrients containing different minerals and vitamins. Eighty-five percents of study population were consumed dark green leafy vegetables, and $81.6 \%$ 
TABLE 3: Factors (crude and adjusted odds ratios and confidence intervals) associated with high dietary diversity in MCH at AGH, Alamata town, $2017(n=412)$.

\begin{tabular}{|c|c|c|c|c|}
\hline Variable & Low & High & COR $(95 \% \mathrm{CI})$ & $\operatorname{AOR}(95 \% \mathrm{CI})$ \\
\hline \multicolumn{5}{|l|}{ Latrine } \\
\hline Yes & 124 & 230 & 1 & 1 \\
\hline No & 36 & 22 & $0.33(0.19,0.59)$ & $0.75(0.336,1.677)$ \\
\hline \multicolumn{5}{|l|}{ Residence } \\
\hline Urban & 116 & 212 & 1 & 1 \\
\hline Rural & 44 & 40 & $0.50(0.31,0.81)$ & $1.30(0.64,2.66)$ \\
\hline \multicolumn{5}{|l|}{ Monthly income } \\
\hline $0-500$ & 9 & 12 & $0.70(0.29,1.71)$ & $1.60(0.54,4.71)$ \\
\hline $501-1500$ & 39 & 27 & $0.36(0.21,0.63)$ & $1.06(0.53,2.12)$ \\
\hline 1501 or above & 112 & 213 & 1 & 1 \\
\hline \multicolumn{5}{|l|}{ Education status } \\
\hline Unable to write and read & 79 & 64 & $0.15(0.07,0.32)$ & $0.67(0.24,2.09)$ \\
\hline Write and read & 20 & 26 & $0.24(0.99,0.59)$ & $0.61(0.19,1.99)$ \\
\hline Elementary school & 22 & 45 & $0.38(0.16,0.88)$ & $1.10(0.36,3.33)$ \\
\hline High school & 29 & 63 & $0.40(0.18,0.90)$ & $0.68(0.25,1.86)$ \\
\hline College and above & 10 & 54 & 1 & 1 \\
\hline \multicolumn{5}{|l|}{ Household education status } \\
\hline Elementary school & 21 & 29 & 1 & 1 \\
\hline Write and read & 29 & 33 & $0.63(0.40,1.74)$ & $1.38(0.57,3.30)$ \\
\hline Unable to write and read & 69 & 49 & $0.51(0.26,0.98)$ & $1.26(0.51,3.11)$ \\
\hline High school & 20 & 44 & $1.56(0.73,3.34)$ & $2.31(0.96,5.58)$ \\
\hline College and above & 21 & 97 & $3.35(1.63,6.88)$ & $2.82(1.19,6.68)^{*}$ \\
\hline \multicolumn{5}{|l|}{ Eating pattern } \\
\hline Two meals and between meal & 71 & 31 & 1 & 1 \\
\hline Three meals and above & 81 & 214 & $0.17(0.11,0.28)$ & $2.66(1.47,4.82)^{*}$ \\
\hline Two meals only or below & 8 & 7 & $0.33(0.12,0.94)$ & $3.07(0.84,8.21)$ \\
\hline \multicolumn{5}{|l|}{ Food security } \\
\hline Food unsecured without hunger & 85 & 38 & 1 & 1 \\
\hline Food secured & 70 & 211 & $6.74(4.23,10.75)$ & $3.85(2.12,6.97)^{*}$ \\
\hline Food unsecured with hunger & 5 & 3 & $1.34(0.31,5.91)$ & $1.32(0.27,6.59)$ \\
\hline \multicolumn{5}{|l|}{ Occupation } \\
\hline Daily laborer & 16 & 10 & 1 & 1 \\
\hline House wife & 84 & 99 & $4.61(1.66,12.77)$ & $2.60(0.80,8.46)$ \\
\hline Merchant & 40 & 85 & $6.24(3.25,9.26)$ & $4.67(1.81,12.05)^{* *}$ \\
\hline Government employee & 14 & 64 & $7.65(6.91,14.81)$ & $4.87(1.70,13.95)^{* *}$ \\
\hline
\end{tabular}

consumed other vegetables (onion, tomato, and egg plants) (Table 2).

More than two-thirds of the study participants had secured food, and $71.6 \%$ of respondents consumed two meals and eating between meals per day. Majority of the respondents $(86.9 \%)$ had no comorbid disease before 4 weeks of data collection (Table 2).

3.2. Factors Associated with High Dietary Diversity. Participants whose education status was college and above were 2.8 times more likely to have high dietary diversity with their diet compared to participants whose education status was elementary school $(\mathrm{AOR}=2.8,95 \%, \mathrm{CI}$ : $1.90-$ 6.68). Those who had three meals and above had greater odds ratio to have high dietary diversity in their diet compared with those who had two meals and between a meal $(\mathrm{AOR}=2.66,95 \% \mathrm{CI}: 1.47-4.82)$. Respondents who had secured food were better to have high dietary diversity than those who had unsecured food without hunger $(\mathrm{AOR}=3.85,95 \% \mathrm{CI}: 2.12-6.97)$. Government employees and merchants have also high dietary diversity in their foods (Table 3 ).

\section{Discussion}

Our study found that major proportion of pregnant women had insufficient minimum dietary diversity intake: this is a poorly emphasized health problem among pregnant women in Ethiopia. We discovered that three-fifths of pregnant women had high dietary diversity score and $38.8 \%$ low dietary diversity score in district urban general hospital during past 24 hours of an interview.

The prevalence of MDDS in this study was higher than the studies conducted in Aksum, Ethiopia; $43.6 \%$ had high dietary diversity scores [14]. Also, we found a higher prevalence of MDDS than the studies done in Kenya and Ghana that found the result of $20 \%$ and $46 \%$ had a high dietary diversity scores consequently $[13,28]$. This difference might be due to their study methodology, mainly variation for the food group involved and its food category, while our study contains 10 food groups with two categories, and their study contained nine food groups with three categories. Additionally, geographical location and seasonal variability may be making difference as in Ghana where the study was done at a rural area characterized by poverty and recurrent drought and flood [28]. 
We found that participants who were college and above level have a good habit of dietary diversity within their diet as compared with those who were elementary school. This might be due to good knowledge about types of food groups that may consume within 24 hours to achieve their dietary diversity level. Women with higher education have a tendency to include a variety of food group and good dietary eating practice in their diet [29]. Less education may be linked with poor food choices and preparation due to lack of knowledge and resources with their dietary diversity [30].

In our study, respondents who had three meals and above had high dietary diversity in their diet compared with those who had two meals and between meals. Conversely, the study done in Pakistan had no association observed between dietary diversity score and nutritional status [8]. This might be related to their economic status. The opportunity of having greater than two meals may have the chance of consuming different categories of meal [31]. Dietary diversity has been strongly associated with socioeconomic status in a household. Individuals with a higher socioeconomic status were found to be consumed a better quality of food diversity than those with a lower socioeconomic status $[2,29]$.

We also found that secured food have high dietary diversity than those who had unsecured food without hunger. This finding was in line with the result in Malaysia that revealed pregnant women who have secured food were more likely to have a higher dietary diversity score than those who have unsecured food [32]. This might be related to accessibility of adequate food due to better attitude and economic status of respondents. Previous studies show that individuals who had inadequate food and low socioeconomic status may lead to little consumption of diverse diets (fruits, vegetables, and milk products) $[33,34]$.

As limitation, dietary diversity was assessed based on responses obtained from participants recall, and this depended on memory and their ability to recall accurately. So, recall bias could not be ruled out completely. The $24-$ hour dietary recall may not truly represent the usual intake.

\section{Conclusions}

This study suggested that around $38.8 \%$ of respondents had a low dietary diversity and $61.2 \%$ had high dietary diversity mainly defined by inclusion of ten food groups. Regarding determinant factors, being house wife and daily laborer, having household elementary school and unsecured food without hunger, eating two meals and between meals were low dietary diversity. Therefore, measures should be taken on dietary diversity and integrate with primary care in the $\mathrm{MCH}$ program.
Abbreviations
AGH: Alamata General Hospital
AIDS: Acquired immune deficiency syndrome
CI: Confidence interval
HIV: Human immune virus
MDDS: Minimum dietary diversity scores
NGO: Nongovernmental Organization.

\section{Data Availability}

The datasets used and/or analyzed during the current study are available from the corresponding author on reasonable request.

\section{Ethical Approval}

Ethical clearance was obtained from Woldia University, Faculty of Health Sciences, Department of Midwifery and Research Committee. The permission letter was taken from AGH.

\section{Consent}

Written informed consent was obtained from each study participant.

\section{Disclosure}

To keep privacy of the respondents, the name and any identity were not included in data collection.

\section{Conflicts of Interest}

The authors declare that they have no conflicts of interest.

\section{Authors' Contributions}

$\mathrm{KJ}$ and MA conceived the study, were involved in the study design, review of the article, analysis, and report writing, and drafted the manuscript. All the authors read and approved the final manuscript.

\section{Acknowledgments}

The authors acknowledge Woldia University for funding this study and Alamata General Hospital and study participants for their cooperation. This research work was funded by Woldia University.

\section{References}

[1] T. Johns and B. R. Sthapit, "Biocultural diversity in the sustainability of developing-country food systems," Food and Nutrition Bulletin, vol. 25, no. 2, pp. 143-155, 2004.

[2] M. Arimond and M. T. Ruel, "Dietary diversity is associated with child nutritional status: evidence from 11 demographic and health surveys," Journal of Nutrition, vol. 134, no. 10, pp. 2579-2585, 2004.

[3] C. Byrd-Bredbenner, G. Moe, D. Beshgetoor, and J. Berning, Wardlaw's Perspectives in Nutrition, McGraw-Hill, New York, NY, USA, 8th edition, 2009.

[4] K. O. O'Brien, N. Zavaleta, L. E. Caulfield, D.-X. Yang, and S. A. Abrams, "Influence of prenatal iron and zinc supplements on supplemental iron absorption, red blood cell iron incorporation, and iron status in pregnant Peruvian women," American Journal of Clinical Nutrition, vol. 69, no. 3, pp. 509-515, 1999.

[5] P. Trumbo, A. A. Yates, S. Schlicker, and M. Poos, "Dietary reference intakes: vitamin $\mathrm{A}$, vitamin $\mathrm{K}$, arsenic, boron, chromium, copper, iodine, iron, manganese, molybdenum, 
nickel, silicon, vanadium, and zinc," Journal of the American Dietetic Association, vol. 101, no. 3, pp. 294-301, 2001.

[6] P. Trumbo, S. Schlicker, A. A. Yates, and M. Poos, "Dietary reference intakes for energy, carbohydrate, fiber, fat, fatty acids, cholesterol, protein and amino acids," Journal of the American Dietetic Association, vol. 102, no. 11, pp. 1621-1630, 2002.

[7] United States Centers for Disease Control and Prevention, Biochemical Indicators of Diet and Nutrition United State, United States Centers for Disease Control and Prevention, Atlanta, GA, USA, 2012.

[8] F. Ali, I. Thaver, and S. A. Khan, "Assessment of dietary diversity and nutritional status of pregnant women in Islamabad, Pakistan," Journal of Ayub Medical College Abbottabad, vol. 26, no. 4, pp. 506-509, 2014.

[9] M. T. Ruel, "Operationalizing dietary diversity: a review of measurement issues and research priorities," Journal of $\mathrm{Nu}$ trition, vol. 133, no. 11, pp. 3911S-3926S, 2003.

[10] J. Kinabo, A. P. Mnkeni, C. Nyaruhucha, J. Msuya, A. Haug, and J. Ishengoma, "Feeding frequency and nutrient content of foods commonly consumed in the Iringa and Morogoro regions in Tanzania," International Journal of Food Sciences and Nutrition, vol. 57, no. 1-2, pp. 9-17, 2006.

[11] Z. S. Lumole, Household Dietary Diversity and Nutritional Status of Children and Women of Reproductive Age in Madizini Township and Its Hinterland Villages, Sokoine University of Agriculture, Morogoro, Tanzania, 2013.

[12] A. Workicho, T. Belachew, G. T. Feyissa et al., "Household dietary diversity and animal source food consumption in Ethiopia: evidence from the 2011 welfare monitoring survey," BMC Public Health, vol. 16, no. 1, p. 1192, 2016.

[13] M. L. Kemunto, Dietary Diversity and Nutritional Status of Pregnant Women Aged 15-49 Years Attending Kapenguria District Hospital West Pokot County, Kenya Kenyatta University Institutional Repository, Nairobi, Kenya, 2013.

[14] N. B. Weldehaweria, K. H. Misgina, M. G. Weldu et al., "Dietary diversity and related factors among lactating women visiting public health facilities in Aksum town, Tigray, Northern Ethiopia," BMC Nutrition, vol. 2, no. 1, p. 38, 2016.

[15] G. Wu, F. W. Bazer, T. A. Cudd, C. J. Meininger, and T. E. Spencer, "Maternal nutrition and fetal development," Journal of Nutrition, vol. 134, no. 9, pp. 2169-2172, 2004.

[16] G. Batcup, Prematurity. Fetal and Neonatal Pathology, pp. 199-222, Springer, Berlin, Germany, 1993.

[17] M. C. Lu and J. S. Lu, Maternal Nutrition and Infant Mortality in the Context of Relationality, Joint Center for Political and Economic Studies, Health Policy Institute, Washington, DC, USA, 2007, https://asphn.org/wp-content/uploads/.../MaternalNutrition-and-Infant-Mortality.pdf.

[18] S. Parets, C. Bedient, R. Menon, and A. Smith, "Preterm birth and its long-term effects: methylation to mechanisms," Biology, vol. 3, no. 3, pp. 498-513, 2014.

[19] H. J. Baer, R. E. Blum, H. R. Rockett et al., "Use of a food frequency questionnaire in American Indian and Caucasian pregnant women: a validation study," BMC Public Health, vol. 5, no. 1, p. 135, 2005.

[20] O. A. Ladipo, "Nutrition in pregnancy: mineral and vitamin supplements," American Journal of Clinical Nutrition, vol. 72, no. 1, pp. 280S-290S, 2000.

[21] L. E. Torheim, E. L. Ferguson, K. Penrose, and M. Arimond, "Women in resource-poor settings are at risk of inadequate intakes of multiple micronutrients," Journal of Nutrition, vol. 140, no. 11, pp. 2051S-2058S, 2010.
[22] H. Gerster, "Vitamin A-functions, dietary requirements and safety in humans," International Journal for Vitamin and Nutrition Research, vol. 67, no. 2, pp. 71-90, 1997.

[23] V. Azaïs-Braesco and G. Pascal, "Vitamin A in pregnancy: requirements and safety limits," American Journal of Clinical Nutrition, vol. 71, no. 5, pp. 1325S-1333S, 2000.

[24] S. J. Hornby, S. J. Ward, and C. E. Gilbert, "Eye birth defects in humans may be caused by a recessively-inherited genetic predisposition to the effects of maternal vitamin A deficiency during pregnancy," Medical Science Monitor, vol. 9, no. 11, pp. HY23-HY26, 2003.

[25] A. Ahmed, Assessment of Dietary diversity among Pregnant and Lactating Women and 6 to 23 Months Age Children in Rural Areas of Western, Ethiopian Public Health Institute, Addis Ababa, Ethiopia, 2014.

[26] E. Becquey and Y. Martin-Prevel, "Micronutrient adequacy of women's diet in urban Burkina Faso is low," Journal of Nutrition, vol. 140, no. 11, pp. 2079S-2085S, 2010.

[27] E. Becquey, G. Capon, and Y. Martin-Prével, "Dietary diversity as a measure of the micronutrient adequacy of women's diets: results from Ouagadougou, Burkina Faso site," in Food and Nutrition Technical Assistance II Project, Academy for Educational Development, Washington, DC, USA, 2009.

[28] M. Saaka, J. Oladele, A. Larbi, and I. Hoeschle-Zeledon, "Dietary diversity is not associated with haematological status of pregnant women resident in rural areas of northern Ghana," Journal of Nutrition and Metabolism, vol. 2017, Article ID 8497892, 10 pages, 2017

[29] K. Murakami, Y. Miyake, S. Sasaki, K. Tanaka, Y. Ohya, and Y. Hirota, "Education, but not occupation or household income, is positively related to favorable dietary intake patterns in pregnant Japanese women: the Osaka Maternal and Child Health Study," Nutrition Research, vol. 29, no. 3, pp. 164-172, 2009.

[30] R. E. Mazur, G. S. Marquis, and H. H. Jensen, "Diet and food insufficiency among Hispanic youths: acculturation and socioeconomic factors in the third National Health and $\mathrm{Nu}-$ trition Examination Survey," American Journal of Clinical Nutrition, vol. 78, no. 6, pp. 1120-1127, 2003.

[31] J. Kearney, "Food consumption trends and drivers," Philosophical Transactions of the Royal Society B: Biological Sciences, vol. 365, no. 1554, pp. 2793-2807, 2010.

[32] M. Mohamadpour, Z. M. Sharif, and M. Keysami, "Food insecurity, health and nutritional status among sample of palm-plantation households in Malaysia," Journal of Health, Population and Nutrition, vol. 30, no. 3, pp. 291-302, 2012.

[33] W. González, A. Jiménez, G. Madrigal, L. M. Muñoz, and E. A. Frongillo, "Development and validation of measure of household food insecurity in urban Costa Rica confirms proposed generic questionnaire," Journal of Nutrition, vol. 138, no. 3, pp. 587-592, 2008.

[34] V. Tarasuk, L. McIntyre, and J. Li, "Low-income women's dietary intakes are sensitive to the depletion of household resources in one month," Journal of Nutrition, vol. 137, no. 8, pp. 1980-1987, 2007. 


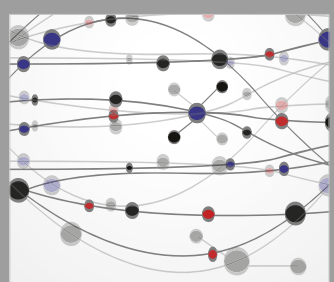

The Scientific World Journal
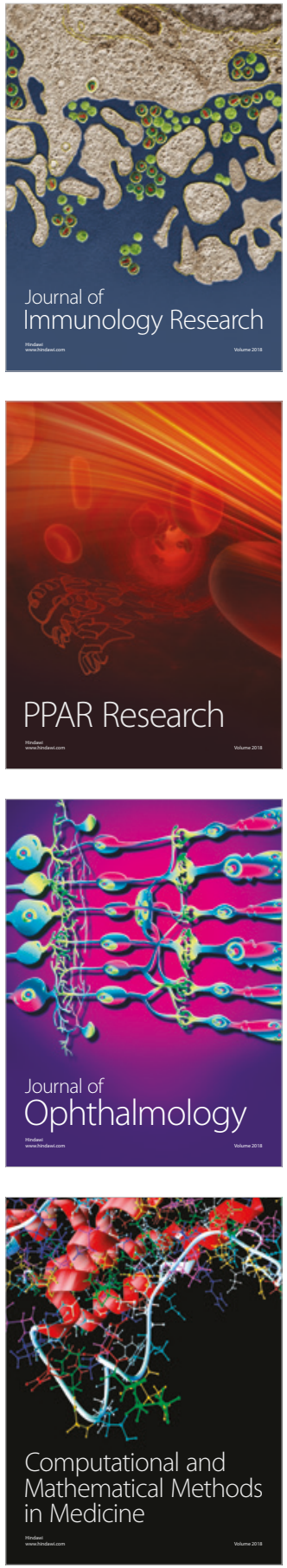

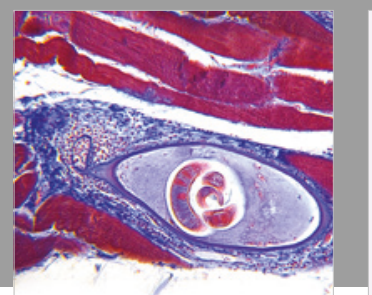

Gastroenterology Research and Practice

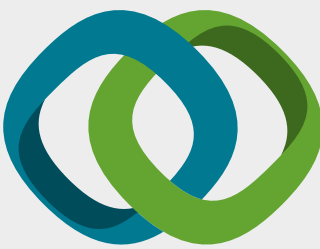

\section{Hindawi}

Submit your manuscripts at

www.hindawi.com
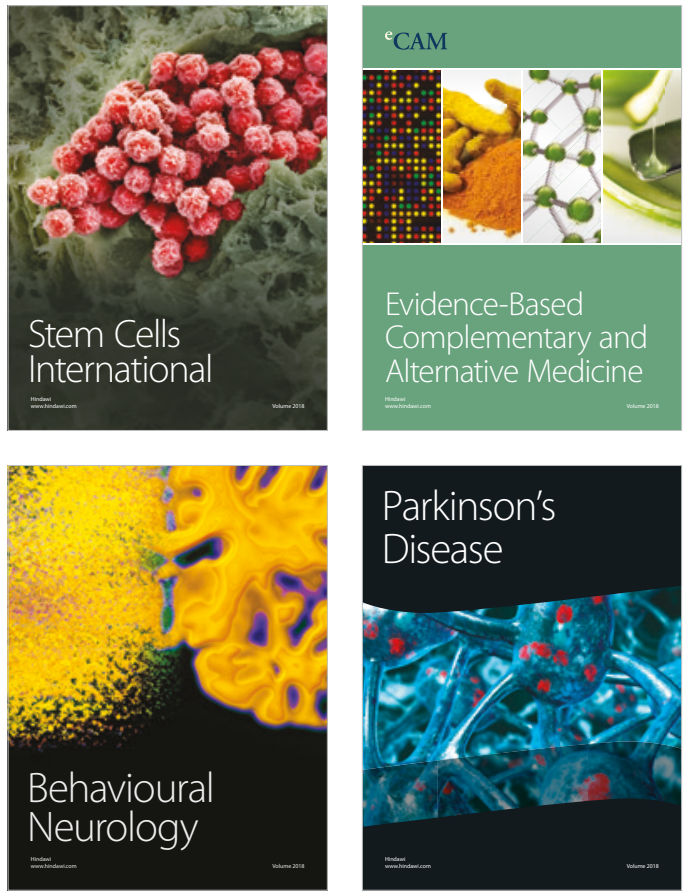

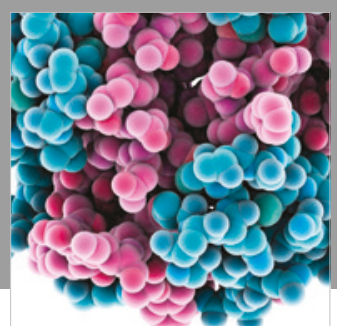

ournal of

Diabetes Research

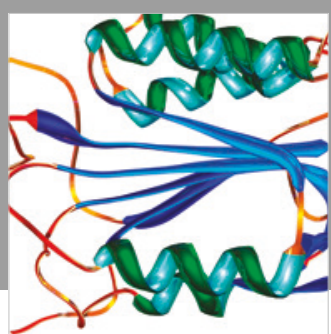

Disease Markers
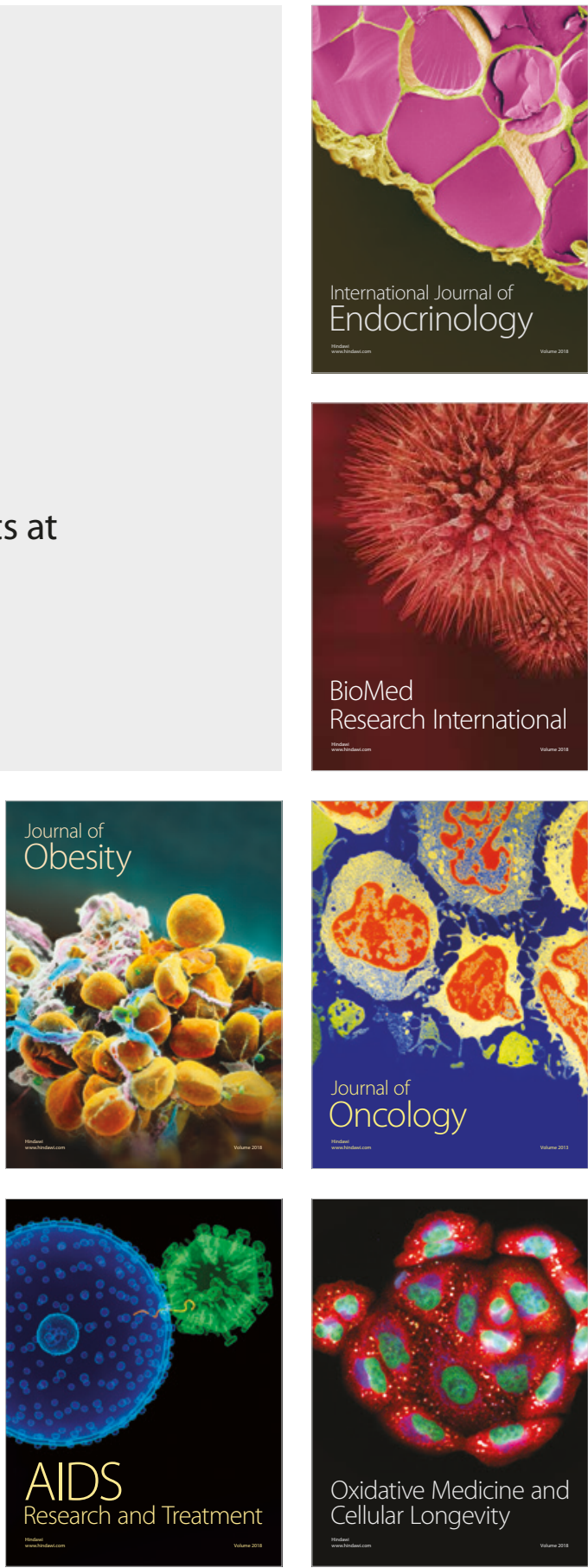